\title{
List of publications of Ernests Fogels
}

1. Dažas ievērojamas skaitlu teorijas problēmas (Some famous problems of the theory of numbers), Izgl. ministrijas mënešraksts, Rīga, 1938 , No. 1, pp. 36-48.

2. Über die Möglichkeit einiger diophantischen Gleichungen 3 und 4 Grades in quadratischen Körpern, Comment. Math. Helv. 10 (1938), pp. 263-269.

3. Some impossible Diophantine equations in the form of $x^{4}+a y^{4}=z^{2}$, Latv. Univers. Raksti, mat. un dabas zin. fak. sērija III, Rīga, 1938, No. 2, pp. 67-74.

4. The general solution of the equation $a x^{2}-b y^{2}=z^{3}$, Amer. J. Math. 60 (1938), pp. 734-736.

5. Über die Möglichkeit diophantischer Gleichungen in relativ quadratischen Zahlenkörpern, Latv. Univers. Raksti, mat. un dabas zin. fak. sērija III, Rīga, 1940, Nó. 9, pp. 273-284.

6. On average values of arithmetical functions, ibid., 1940, No. 16, pp. 285-313.

7. Problēmas par aritmëtiskām funkcijām (Problems in arithmetical functions), Latv. Univers. matem. stud. b-bas Raksti, Rīga, 1940, No. 1, pp. 26-30.

8. Aditīvas teoremas par kvadrātiskiem atlikumiem (Additive theorems in quadratic residues), ibid., pp. 31-35.

9. On average values of arithmetic functions, Proc. Cambridge Philos. Soc. 37 (1941), pp. 358-372.

10. Zur Arithmetik quadratischer Zahlenkörper, Univers. Raksti, matem. I, Rīga, 1943, No. 2, pp. 23-47.

11. Par statistisko masu salìdzināšanu (On the comparison of statistical masses), Ž. Latv. ekonomists, 1943, No. 9/10, 15/16, 9 pp.

12. Korelāciju metode (Correlation method), ibid., 1943, No. 11/12, 13/14, 19/20, 23/24, 25 pp.

13. Pētīumi par asimptotiski vienmërīgi sadalītu skaitlu virknēm (Investigations on sequences of asymptotically uniformly distributed numbers), Dissert. zinātṇu doktora grāda iegūšanai (Thesis to obtain the degree of the doctor of science), Riga, 1943, $50 \mathrm{pp}$.

14. О простых числах некоторых квазилинейных прогрессий (On primes in some quasilinear progressions), Latvijas PSR Zinātṇu Akadēmijas Vēstis, Fizikas un tehnisko zinātp̣u sērija, 1948, No. 1 (6), pp. 97-135.

15. О простых числах арифметической прогрессии (On primes in arithmetical progression), ibid., 1948, No. 4 (7), pp. 109-124.

16. О последовательностях Варинга (On Waring sequences), ibid.,1948, No. 7 (12), pp. 91-100.

17. Par aritmetikas aksiomām (On axioms of arithmetic), ibid., 1949, No. 3 (20), pp. 97-101.

18. Par dažādu pakāpju aritmētiskām operacijām (On arithmetical operations of different steps), ibid., 1949, No. 12 (29), pp. 145-150.

19. Об элементарном доказательстве теоремы простых чисел (On an elementary proof of the prime number theorem), Latvijas PSR Zinātṇu Akadēmija, Fizikas un matematikas institūta Raksti, 1950, No. 2, pp. 1445.

20. Аналог теоремы Брун-Тичмариа (Analogue of the Brun-Titchmarsh theorem), ibid., pp. 46-58.

21. Par aritmētisku teorēmu finitiem pierādīumiem (On finite proofs of arithmetical theorems), Latvijas PSR Zinātp̣u Akadēmija Vēstis, Fizikas un tehnisko zinātp̣u sērija, 1950, No. 6 (35), pp. 81-86. 
22. Финитное доказательство формул Гаусса-Дирихле (Finite proof of the Gauss-Dirichlet formula), ibid., 1950, No. 9 (38), pp. 117-125.

23. Элементарное доказательство формул Валле-Пуссена (An elementary proof of formulae of de la Vallée-Poussin), ibid., 1950, No. 11 (40), pp. 123-130.

24. Финитная теория элементарных функиий, I. Логарифмическая и показательная функиия (Finite theory of elementary functions, I. Logarithmical and exponential functions), Latvijas PSR Zinātnu Akadēmijas Vēstis, 1951, No. 5 (46), pp. 801-813.

25. Финитные доказательства некоторых результатов аналитической теории чисел (Finite proofs of some results of the analytical number theory), Latvijas PSR Zinātpu Akadēmija, Fizikas institūta Raksti, 1952, No. 3, pp. 49-63.

26. Пример нелинейной прогрессии, содержсащей бесконечное множество простых чисел (An example of a nonlinear progression containing infinitely many prime numbers), Ученые записки Ленинград. унив., сер. физ.-мат. наук 6 (1952), pp. 7-12.

27. О простых числах в начале арифметической прогрессии (On prime numbers at the beginning of an arithmetical progression), Докл. Акад. Наук СССР 102 (1955), pp. 455-456.

28. О простых числах в коротких арифметических прогрессиях (On prime numbers in short arithmetical progressions), ibid. 133 (1960), pp. 1038-1040.

29. On the existence of primes in short arithmetical progressions, Acta Arith. 6(1961), pp. 295-311.

30. О распределении простых идеалов (On the distribution of prime ideals), Докл. Акад. Наук CCCP 140 (1961), pp. 1029-1032.

31. О простых числах в последовательностях норм идеалов (On prime numbers in sequences of norms of ideals), Latvijas PSR Zinātp̣u Akadēmijas Vēstis, 1961, No. 12 (173), pp. 29-34.

32. On the zeros of Hecke's L-functions, I, Acta Arith. 7 (1962), pp. 87-106.

33. On the zeros of Hecke's L-functions, II, ibid. 7 (1962), pp. 131-147.

34. On the zeros of Hecke's L-functions, III, ibid. 7 (1962), pp. 225-240.

35. On the distribution of prime ideals, ibid. 7 (1962), pp. 255-269.

36. О распределекии аналогов простых чисел (On the distribution of analogues of primes), Докл. Акад. Наух СССР 146 (1962), pp. 318-321.

37. Об абстрактной теории простых чисел (On the abstract theory of prime numbers), Latvijas PSR Zinātpu Akadēmijas Vēstis, 1963, No. 1 (186), pp. 75-80.

38. Über die Ausnahmestelle der Heckescher L-Funktionen, Acta Arith. 8 (1963), pp. 307-309.

39. On the abstract theory of primes, $I$, ibid. 10 (1964), pp. 137-182.

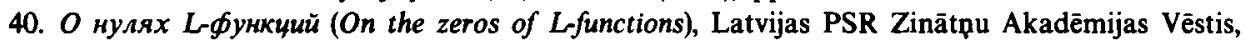
Fizikas un tehnisko zinātṇu sērija, 1964, No. 5, pp. 31-35.

41. Par profesora E. Lejnieka zinätnisko darbu (On the scientific work of Professor E. Lejnieks), Zvaigžpotā debess, 1964, g. vasara, No. 24, pp. 41-45.

42. (With 8 co-authors) Работы математиков Советской Латвии за последнее семилетие (Work of mathematicians of the Soviet Latvia during the last seven years), Latvijas PSR Zinātpu Akadēmijas Vēstis, Fizikas un tehnisko zinātp̣u sērija, 1965, No. 3, pp. 3-26.

43. On the abstract theory of primes, $I I$, Acta Arith. 10 (1965), pp. 333-358.

44. On the zeros of L-functions, ibid. 11 (1965), pp. 67-96; corrigendum: 14 (1968), p. 435.

45. On the abstract theory of primes, III, ibid. 11 (1966), pp. 293-331.

46. О простых числах, представляемых бинарной квадратичной бормой (On primes representable by a binary quadratic form), Latvijas PSR Zinātṇu Akadēmijas Vēstis, Fizikas un tehnisko zinātp̣u sērija, 1966, No. 1, pp. 71-79.

47. Большое peuemo (The large sieve), ibid., 1969, No. 4, pp. 3-14.

48. Approximate functional equation for Hecke's L-functions of quadratic field, Acta Arith. 16 (1969), pp. 161-178.

49. Srinivasa Ramanudžans, Zvaigžnotā debess, 1970, g. rudens, No. 49, pp. 34-38.

50. On the zeros of a class of L-functions, Acta Arith. 18 (1971), pp. 153-164. 
51. A mean value theorem of Bombieri's type, ibid. 21 (1972), pp. 137-151.

52. On shifted primes, ibid. 27 (1975), pp. 333-352.

53. О нулях дзета-функции Римана (On the zeros of Riemann zeta-function), Latvijas PSR Zinātṇu Akadēmijas Vēstis, Fizikas un tehnisko zinātp̣u sērija, 1980, No. 4 (393), pp. 136-144.

54. Об одной zuпотезе в теории простых чисел (On a hypothesis in the theory of prime numbers), ibid., 1980, No. 10 (399), pp. 68-74. 